\title{
Was C. Rubellius Blandus Involved in the Exploitation of the Silver Mines of Carthago Nova?*
}

\begin{abstract}
The mention of three members of the gens Rubellia in two funerary inscriptions recovered from an important mining complex located near Carthago Nova allows us to consider the possibility that the Rubellii Blandi from Tibur might be involved in the mining activity. Consequently, the wedding of Tiberius' niece, Julia, to C. Rubellius Blandus could be related to the princeps' interests in controlling the silver mines of the south-est of Spain.

Keywords: Rubellii Blandi - Silver Mines - Carthago Nova - Roman Spain.
\end{abstract}

\section{1.}

In the year 33 Tiberius' niece, Julia, married C. Rubellius Blandus. Tacitus relates this event in his Annales with astonishment ${ }^{1}$. Julia had been married to Nero Julius Caesar, the son of Germanicus, and was about 30 years old ${ }^{2}$. Blandus, on the contrary, was in his sixties. His grandfather had been a mere eques and he was the first in his family to become a consul ${ }^{3}$. R. Syme considered the fact so intriguing that he wrote in 1982 a detailed study in which he tried to reveal the keys of the ascent of this little-known family and the motives which led Tiberius to arrange such a strange marriage ${ }^{4}$.

The Rubellii Blandi were from Tibur's. The father of C. Rubellius Blandus was praetor and governor of Crete and Cyrenaica ${ }^{6}$. His full name was probably C. Rubellius L.f. Blandus, if it is correct to identify him with the person mentioned on a fragment of inscription

* I would like to thank M.J. Pena and J.A. Antolinos for their generous comments and suggestions. This study is part of the project FFI2015-63981-C3-3-P, financed by the Ministry of Economy and Competitiveness of Spain

1 Tac. Ann. 6.27.1: “Tot luctibus funesta civitate, pars maeroris fuit quod Iulia Drusi filia, quondam Neronis uxor, denupsit in domum Rubellii Blandi, cuius avum Tiburtem equitem Romanum plerique meminerant", "Among all the griefs of a melancholy realm, it was a contributory regret that Julia, daughter of Drusus and formerly wife of Nero, now married into the family of Rubellius Blandus, whose grandfather was remembered by many as a Roman knight from Tibur" (trans. by J. Jackson); cf. Dio 58.21.1.

$2 \quad P I R^{2} \mathrm{I} 636$.

$3 \quad P I R^{2} \mathrm{R} 111$.

4 Syme 1982

5 Three inscriptions related to important members of this family are known in Tibur (CIL XIV $3555=$ Isc.It. IV.1, 6o; CIL XIV 3556 = Isc.It. IV.1, 61; CIL XIV 3576 = Isc.It. IV.1, 76, cf. Andermahr 1998, 414-5), as well as one belonging to one of their freedwomen (CIL XIV $3832=$ Isc.It. IV.1, 432).

$6 \quad P I R^{2} \mathrm{R} 109$. 
which belongs to the architrave of the southern propylaea of the Caesareum of Cyrene ${ }^{7}$. Probably he is also mentioned in another inscription from Marruvium, where, in addition to his filiation, his tribe is indicated, the Camilia, which is the one of Tibur'. His grandfather was an eques who achieved fame as teacher of rhetoric ${ }^{9}$. The sources do not mention his praenomen, but thanks to the inscriptions of Cyrene and Marruvium, it may be supposed that he was called Lucius. Another C. Rubellius, perhaps his brother, is mentioned in the letters of Cicero together with various negotiatores with interests in Africa ${ }^{10}$. Before marrying Julia, C. Rubellius Blandus was a consul suffectus in the year $18 \mathrm{AD}$. He might be identified with a triumvir monetalis who was active around the year $4 \mathrm{AD}^{11}$. Tacitus remembers two of his interventions in the Senate ${ }^{12}$. Given his age it is very likely that he would have been married already, although we have no information regarding this. After marrying Julia he was a governor of the Roman province of Africa Proconsularis ${ }^{13}$. During his governorship he could have acquired the saltus Blandianus, near the river Medjerda ${ }^{14}$, although it is also possible that these lands belonged to the family since the time of the $\mathrm{C}$. Rubellius mentioned by Cicero ${ }^{15}$. Another L. Rubellius Geminus was a consul in the year 29 and a [C. vel L.] Rubellius Blandus, was consul suffectus in $21-22$ or $40-45$. Their relationship to Julia's husband is difficult to determine. They might be younger brothers, cousins or even sons from a first marriage ${ }^{16}$. The marriage to Julia gave various children ${ }^{17}$, one of which, Rubellius Plautus, would be murdered by the emperor Nero, his half-cousin ${ }^{18}$.

It is very complicated indeed to understand how the Rubellii evolved in scarcely two generations from being simple domi nobiles to forming part of the nucleus of the reigning dynasty, since, moreover, apart from the grandfather, [L.] Rubellius Blandus, none of its members had stood out in anything. The marriage of Julia and Blandus is a difficult event to explain, even when taking into account the implication of the bride's mother, Livia Julia, in the conspiracy of Sejanus". Syme himself affirms that "[the] rise of the Rubellii is one of those casual facts that dispel conventional notions about Roman political life", and adds: "What obligation [Tiberius] honoured in promoting the Rubellii and in finally introducing this municipal strain into alliance with the dynasty, that cannot be known" ${ }^{20}$. portant works of restoration due to the damage caused during the Jewish revolt of 115. These works proba-
bly included also the restoration of the inscription made by Blandus, Luni 1991, 132-40.

$A E 1975305=A E$ 1996, 305; cf. Letta and D'Amato 1975, 84-92.

$P I R^{2} \mathrm{R} 108$.

Cic. Fam. 12.26.1; Syme 1982, 65-6.

$P^{2} \mathrm{R}$ 110; RIC I $\mathrm{I}^{2} 467$.

Tac. Ann. 3.23.2; 3.51.1.

Thomasson 1996, 31-2.

CIL VIII 25943, 26416; Flach 1978, 484-9. Cf. Carcopino 1906, 436; Kolendo 1991, 11; Andermahr 1998, 35. Syme 1982, 65 .

$P I R^{2} \mathrm{R} 107$ and 113 .

$P I R^{2} \mathrm{R} 106,112,115$ and 116.

Tac. Ann. 14.22; 14.57-59; cf. Syme 1982, 79-81; Cogitore 2002, 228-34.

PIR L 303; cf. Bellemore 1995; Birley 2007.

Syme 1982, 77 . 
However, overlooked evidence from Spain suggests a likely explanation for the rise of the Rubellii. In one of the most important mining complexes of the south-east of Spain, the Coto Fortuna ${ }^{21}$, two funerary inscriptions were discovered in the $19^{\text {th }}$ Century. They were made by an individual called L. Rubellius Philodamus for his parents Alexandra and L. Rubellius Philostratus ${ }^{22}$. Both belonged to the same funerary monument and probably were made in the local workshops of the nearby Carthago Nova ${ }^{23}$. Their characteristics allow them to be dated in the first half of the $1^{\text {st }}$ century $\mathrm{AD}$. At this time mining activity in the Coto Fortuna was managed by a big mining company: the societas argentifodinarum Ilucronensium, which also had interests in other mines of the region ${ }^{24}$. The finding of these two inscriptions in the heart of the Coto Fortuna indicates that the persons mentioned on them actually lived there. It is highly likely, therefore, that they were involved in the activity of that mining company. The fact that the Rubellii had their own funerary monument at Coto Fortuna also indicates that they were an important family there.

Rubellius is a very rare nomen. Only a few examples are known in Italy ${ }^{25}$. Outside Italy they are even rarer $^{26}$. In Spain we only know those from Coto Fortuna. The striking scarcity of Rubellii leads R. Syme to consider that most of them may have belonged to the same family, bearing in mind also that the most frequent praenomina among them were Lucius and Caius, both used by the Rubellii Blandi ${ }^{27}$. So, it is not illogical to think that the Rubellii from Coto Fortuna could be related to the Tiburtine Rubellii Blandi. The chronology of their epitaphs indicates that they lived between the end of the $1^{\text {st }}$ century BC and the beginnings of the following. The father, L. Rubellius Philodamus, was contemporary with the eques [L.] Rubellius Blandus. Given the rarity of the nomen and the coincidence of the praenomina, it is even possible that he was one of his freedman.

CIL II 353

suo f.c.; AE 1974, 378 = HEp online 4597: Alexandra/hic sita est/L. Rubellius /Philodamus / filius de suof.c.; cf. Antolinos, Díaz and Guillén 2013, 101-3.

23 Cf. Abascal and Ramallo 1997, 27-30.

24 Antolinos and Díaz 2012.

25 Excluding the inscriptions which surely refer to the members of the Rubellii Blandi family, this nomen is only mentioned in three funerary inscriptions from Northern Italy (Ateste, CIL V $2676+2660=$ Sup.It. 15, 162: C. Rubellius Horionus, L. Rubellius C.f. and C. Rubellius C.f.; Padova, CIL V 3024: T. Rubellius L.f. Pudens; Milano, CIL V 5994: Rubellia Tyranni[s]), in another from Etruria (Lucca, CIL XI 1539: Rubellia Proc(u)la), as well as in a titulus pictus from Pompei (CIL IV 842: Rubellius). In the city of Rome, it is documented in four funerary inscriptions, probably belonging to freedmen of Rubellii Blandi or their descendents (CIL VI 21979: L. Rubellius L.1. Felix; 25502: Sergio Rubellio Antho and Rubellia Laudice; 25503: L. Rubellius T.f. Geminus Caesianus; 25504, Rubellia Ampliata and L. Rubellius Beryllus).

26 The name is attested in two inscriptions from the Africa Proconsularis (CIL VIII 11715: C. Rubellius Niger; ILAlg I 1867: Rubellia Blanda), in one from Sardinia (CIL X 7697: C. Rubellius Clytius) and, with doubts, in one from Gallia Belgica (CIL XIII 11457: [R] ubellius) and another from Nimes (Fiches and Veyrac 1996, 509: Paula Rubelli f.). From Sicily, we have a sigillum of bronze belonging perhaps to a freedman of the Rubellii Blandi (CIL X 8059, 343: C. Rubellius Evemerus; cf. Manganaro 2006, 23).

27 
He may also have been a freedman of other members of the family, such as the consul of the year $29 \mathrm{AD}$. The presence of freedmen of the Rubellii Blandi in Coto Fortuna could be taken to indicate the participation of this family in the mining activity which was carried out there.

We are aware of various families whose political rise seems to be related to their involvement in the exploitation of the Carthago Nova silver mines. A clear case is that of the Nonii Asprenates ${ }^{28}$. The same could be said of the Turullii' ${ }^{29}$, the Roscii from Lanuvi$u^{30}{ }^{30}$ and perhaps the Favonii from Tarracina ${ }^{31}$. It is also probable that various members of the Caesar's entourage such as M. Aquinius, L. Aurrunculeius Cotta or C. Messius were involved in the mining activity ${ }^{32}$. If we accept the connection of the Rubellii Blandi with the Rubellii of Coto Fortuna their meteoric rise no longer seems an anomaly. On the contrary, it would be the latest example, and perhaps the most spectacular, of those families of domi nobiles, some of them from the local aristocracies of the Lazio, which progressed in the context of the Civil Wars of the $1^{\text {st }}$ Century BC thanks to the profits obtained in the Spanish mines. The reasons for the marriage between the niece of Tiberius and $\mathrm{C}$. Rubellius Blandus would also be evident: the marriage have allowed the princeps a greater control over the silver mines of Carthago Nova.

\section{Bibliography}

Abascal, J.M. and Ramallo, S.F. 1997: La ciudad de Carthago Nova: la documentación epigráfica, Murcia.

Antolinos, J. A. and Díaz, B. 2012: "La societas argentifodinarum Ilucronensium y la explotación de las minas romanas de Carthago Nova", Chiron 42, 25-43.

Antolinos, J. A., Díaz, B. and Guillén, M. C. 2013: "Minería romana en Carthago Nova: el Coto Fortuna (Murcia) y los precintos de plomo de la societas argentifodinarum Ilucronensium", JRA 26, $88-121$.

Andermahr, M. A. 1998: Totus in praediis: Senatorischer Grundbesitz in Italien in der Frühen und Hoheb Kaiserzeit, Bonn.

Barreda, A. 1996: "Los Nonii Asprenates en la Hispania republicana", AnMurcia 11-12, 245-55.

Bellemore, J. 1995: “The wife of Sejanus”, ZPE 109, 255-66.

Birley, A. 2007: "Sejanus: His Fall”, in N. Sekunda (ed.), Corolla Cosmo Rodewald, Gdańsk, 121-50.

Carcopino, J. 1906: “L'Inscription d'Aïn-el-Djemala. Contribution à l'histoire des saltus africains et du colonat partiaire", MEFRA 26, 365-481.

Cogitore, I. 2002: La légitimité dynastique d'Auguste à Néron à l'èpreuve des conspirations, Rome.

Díaz, B. and Antolinos, J. A. 2011: "Una inscripción funeraria republicana procedente de Los Beatos (Cartagena, Murcia)", ZPE 179, 291-4

Domergue, Cl. 1990: Les mines de la Péninsule Ibérique dans l'antiquité romaine, Rome.

Fiches, J. L. and Veyrac, A. 1996: Carte archéologique de la Gaule 30.1, Nimes, Paris.

Flach, D. 1978: "Inschriftenuntershungen zum römischen Kolonat in Nordafrika”, Chiron 8, 441-92.

Wiseman 1971, 244-245; Barreda 1996.

Wiseman 1971, 199 and 268; Koch 1984, 240-1.

Wiseman 1971, 199 y 256; González and Olivares 2010, 113.

Díaz and Antolinos 2011.

Wiseman 1971, 214 and 240-41; Domergue 1990, 327-8. 
Gasperini, L. 1971: "Le iscrizioni del Cesareo e della Basilica di Cirene”, QuadALibia 6, 3-2.

González, R. and Olivares, J. C. 2010: "Una inscripción de época republicana dedicada a Salaecus en la región minera de Carthago Noua”, AEspA 83, 109-26.

Koch, M. 1984: "Die Turullii und Neukarthago", Navicula Tubingensis. Studia in honorem Antonii Tovar, Tübingen 1984, pp. 233-46.

Kolendo, J. 1991: Le colonat en Afrique sous le haut-empire, Paris.

Letta, C. and D’Amato, S. 1975: Epigrafia della regione dei Marsi, Milano.

Luni, M. 1991: “Strutture monumentali e documenti epigrafici nel Foro di Cirene”, L’Africa Romana 9, $123-46$.

Syme, R. 1982: "The Marriage of Rubellius Blandus", AJPh 103.1, 62-85.

Thomasson, B. E. 1996: Fasti Africani. Senatorische und ritterliche Amtsträger in den römischen Provinzen Nordafrikas von Augustus bis Diokletian, Stockholm.

Wiseman, T. P. 1971: New Men in the Roman Senate, Oxford.

BORJA DÍAZ ARIÑO

Departamento de Ciencias de la Antigüedad, Universidad de Zaragoza, C/ Pedro Cerbuna, 12 50009, Zaragoza, Spain, bdiaz@unizar.es 